\title{
Telstra Financial Analysis Report Fy2009 - Fy2013
}

\author{
Wei Xin \\ Finance, College of Business and Economics, Australian National University, Canberra, Australia
}

\author{
Email address: \\ xinweiruc@163.com
}

\section{To cite this article:}

Wei Xin. Telstra Financial Analysis Report Fy2009 - Fy2013. Journal of Finance and Accounting. Vol. 3, No. 5, 2015 , pp. 150-158. doi: $10.11648 /$ j.jfa.20150305.16

\begin{abstract}
Telstra, short for Telstra Corporation Limited, is avery successful company in Australia. Based on their financial report published these years, we can analyse the feature and how it performed these years. In the article we used horizontal analysis and ration analysis.Based on the external factors, business environment, the financial analysis and the estimated future share price, it is strongly recommended that Telstra is a good investing choice for investors and it will be seen beneficial in both short run and long run.
\end{abstract}

Keywords: Telstra, Analysis, Ratio, Return

\section{Horizontal Analysis}

\subsection{Total Assets over Years}

According to trend of balance sheet above, the current assets of Telstra in 2013 dropped rapidly by approximately $21 \%$ from 2012 after a steady increase each year since that 2009. It mainly resulted from the reduction in cash and cash equivalents, which decreased by more than $37.16 \%$.It is because, in 2013, Telstra committed a serious of acquisitions, which spend purchase consideration of more than 1000 million in cash. With financial crisis became severer, acquisition of small telecom and IT companies did become an efficient way for Telstra to diversify its business (improve its service ability), increase its market share and respond competition in telecom industry. Indeed, this strategy brined great benefits to Telstra. It not only helped Telstra maintain the growth rate of $1.2 \%$ in sales revenue, but also increased service revenue by $123 \%$. In addition, the amount of inventory in 2013 raised by $66 \%$ when compared with that of 2012 while the amount was almost consistent in about 140 million during previous years. Actually, since 2013, in order to attract customers, company started to carry out marketing policy that they provide free internet routers to new customers. Therefore, it explained the increase of inventory. Besides the cash and inventory, after a big decrease by $52 \%$ and $61 \%$ in 2011 and 2012, Telstra's financial assets climbed by $34 \%$; it was explained that, in 2013, Telstra signed an agreement to dispose of its shareholdings in TelstraClear Limited, which then transferred into assets ofheld for sales.
In detail, there was $3.55 \%$ increase in the non-current assets in 2013 , stopping the average $4 \%$ reduction each year from 2009. This change was due to development of new software system which caused increase in intangible assets. In general, the non-current assets of Telstra were steadier over the last 5 years and they were relatively unchanged compared to 22013 .

Due to the changes in both current assets and non-current assets, the total assets of ORI reduced from 2008 over last 5 years. Especially, the total assets of ORI in 2010 were the lowest compared to other years.

\subsection{Total Liabilities and Net Assets over Years}

Moreover, the current liabilities of Telstra in 2013 dropped by approximately $29.6 \%$ compared to its in 2012 . This trend reflected a recovery of company's bad financial condition in last four years when 12\% higher liability in 2009 than 2008 and $25 \%$ higher liability in 2012 than 2011 . According to financial statement, the drops in liability were resulted from the reduction on current borrowings and financial liabilities. In contrast, the non-current liabilities decreased by $10 \%$ and $3 \%$ in 2009 and 2010, yet they increased a little by $0.4 \%$ and $5.6 \%$ in the following two years, reaching the highest in 2013. The fluctuation is in accordance with the change of non-current interest-bearing bonds. It was because that the increase of non-current borrowing overweighted the decrease of current borrowings, the finance expenses climbed by about $2.36 \%$. For the financial liabilities, it was relatively high in 2009 and 2010 and since 2011, the growth rate became slower. Telstra's financial liabilities were mainly used in response of company's hedging policy. In order to hedge the future 
business risks, the company purchased a great deal of forwards, futures and options from 2009. However, the financial liabilities increased significantly the total liability, thus influenced company's financial position. Therefore, Telstra reduced its financial liabilities by selling since 2012 and it explained the decrease of amount of this account afterwards.

In general, although there was an increase on current liability, total liability increased by about $7 \%$ because of the influence of non-current liability. Thus, the total liabilities was highest in 2012 (102.5\% of 2009) and then declined $7 \%$ in 2013.

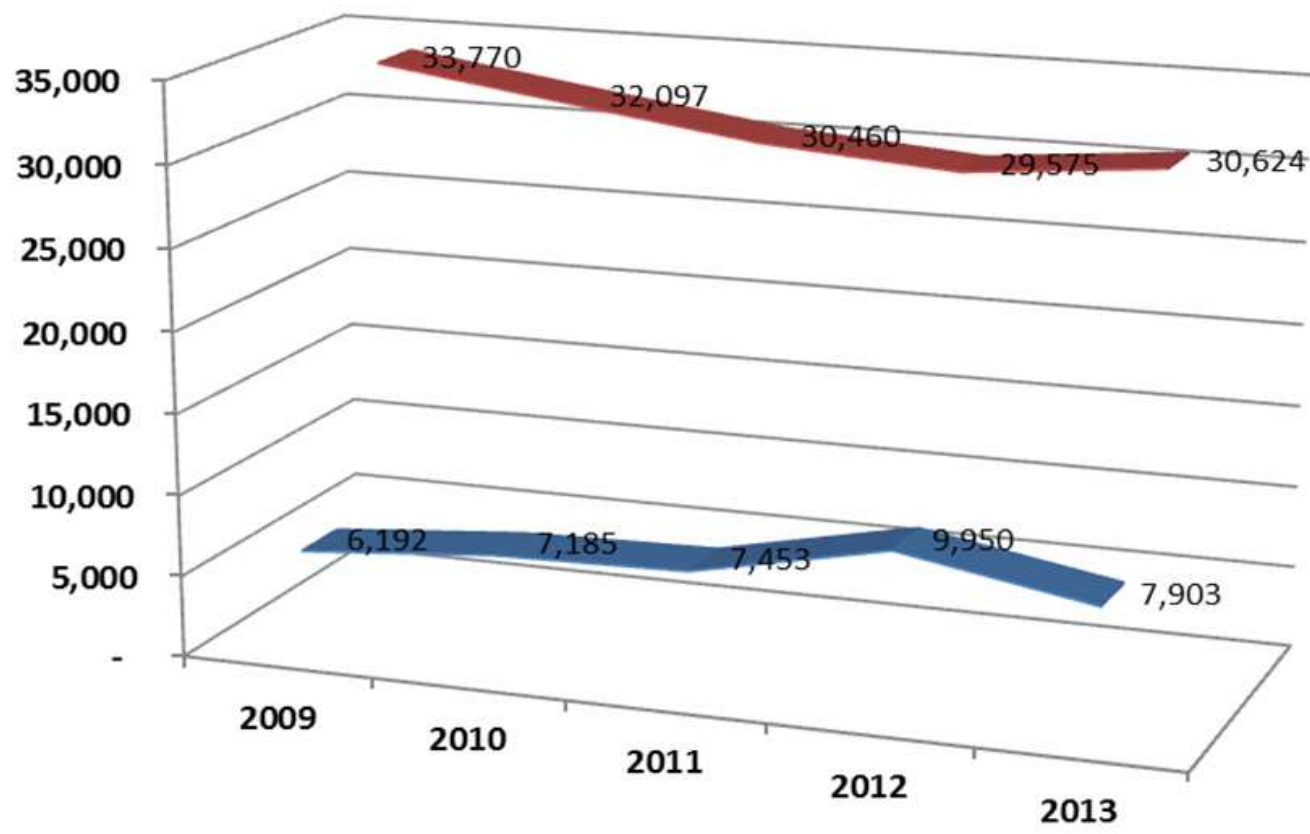

- Total NC assets

Total current assets

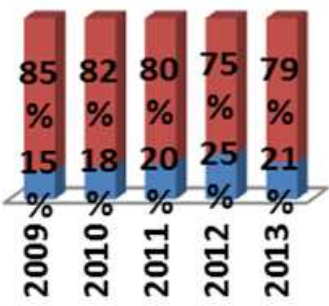

- lotal current assets

Total NC assets

Figure 1. Trend diagram of assets.

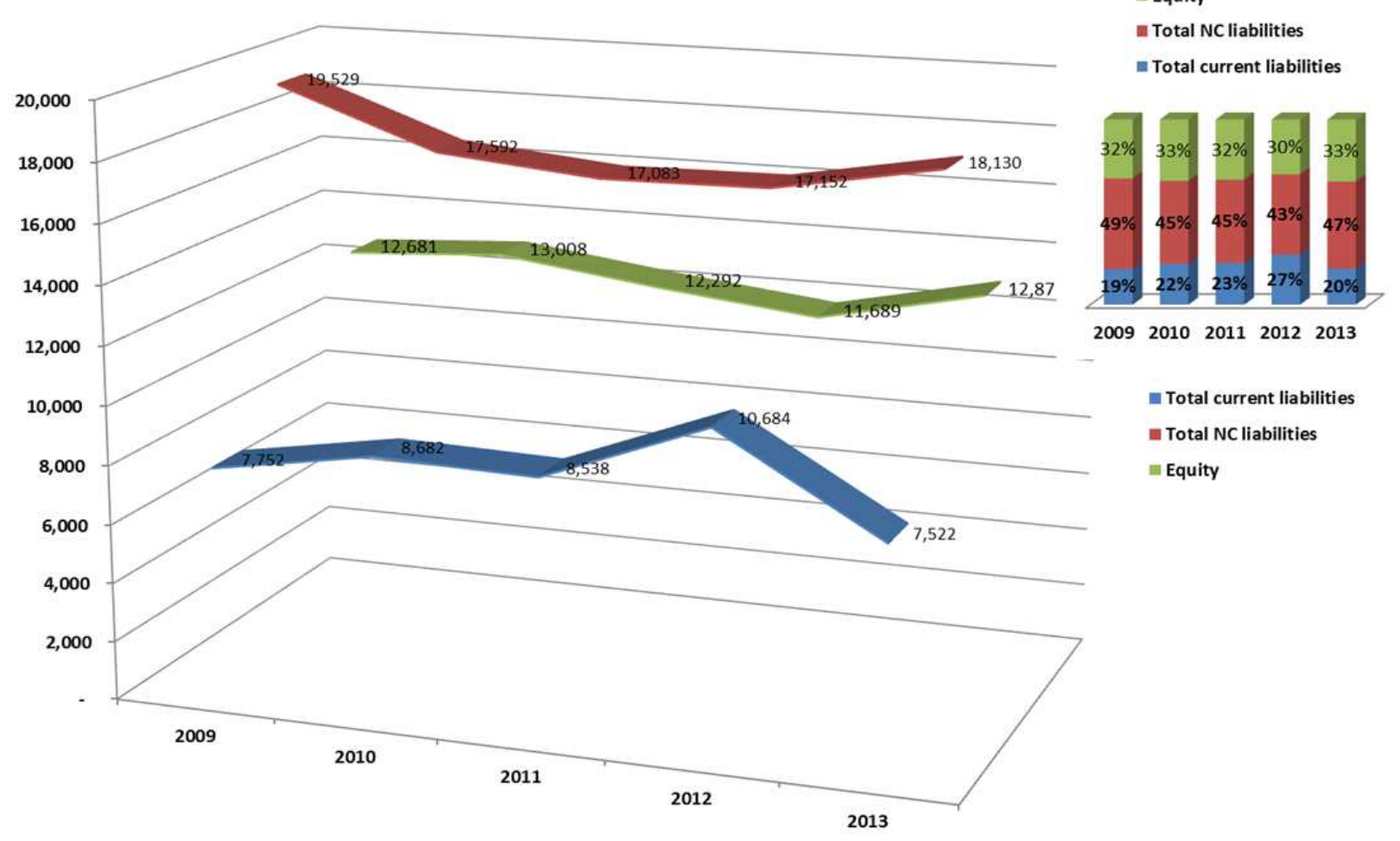

Figure 2. Trend diagram of liabilities and equity. 


\subsection{Total Equity}

In generally, the total equity of Telstra reduced each year from 2010 by $5 \%$ in average. In 2013, it increased more than $10 \%$ in comparison with that in 2012. It resulted from the large increase in retained earnings attributable to ordinary shareholders and minority interest. To connect with the movement in income statement, improvement in net profit directly explained the positive fluctuation in retained earnings.
Although the retained earnings determined the trend of total equity, the reduction of reserve equity should also be highlighted. According to the notes to financial statements, the reduction of reserve equity accumulated each year from 2009 due to the accumulation of unrealized loss on foreign currency translation (translation of overseas controlled entities) caused by the strong Australian dollar and the accumulation of equity arising from purchase of non-controlled entities equity.

Table 1. Trend analysis of balance sheet.

\begin{tabular}{|c|c|c|c|c|}
\hline Telstra's balance sheet & 2010 vs. 2009 & 2011 vs. 2010 & 2012 vs. 2011 & 2013 vs. 2012 \\
\hline Total assets & $12.00 \%$ & $-1.66 \%$ & $25.13 \%$ & $-29.60 \%$ \\
\hline Current Assets & $16.04 \%$ & $3.73 \%$ & $33.50 \%$ & $-20.57 \%$ \\
\hline Trade and other receivables & $-1.44 \%$ & $3.92 \%$ & $5.05 \%$ & $4.86 \%$ \\
\hline Inventory - closing & $23.43 \%$ & $-4.07 \%$ & $-8.13 \%$ & $65.77 \%$ \\
\hline Derivative financial assets & $35.16 \%$ & $-52.02 \%$ & $-61.45 \%$ & $34.38 \%$ \\
\hline Investment & $12.50 \%$ & $-83.33 \%$ & $933.33 \%$ & $80.65 \%$ \\
\hline PPE & $-4.19 \%$ & $-4.82 \%$ & $-5.90 \%$ & $-0.87 \%$ \\
\hline Intangibles & $-4.61 \%$ & $-5.00 \%$ & $-2.70 \%$ & $10.52 \%$ \\
\hline $\mathrm{NC}$ tax receivables & $86.63 \%$ & $19.00 \%$ & $-79.06 \%$ & $-100.00 \%$ \\
\hline Defined benefit assets & $-12.50 \%$ & $57.14 \%$ & $-45.45 \%$ & $-16.67 \%$ \\
\hline Total liabilities & $-3.69 \%$ & $-2.49 \%$ & $8.65 \%$ & $-7.85 \%$ \\
\hline Payables & $2.92 \%$ & $6.51 \%$ & $0.93 \%$ & $2.66 \%$ \\
\hline Borrowings & $28.35 \%$ & $-21.65 \%$ & $66.13 \%$ & $-77.28 \%$ \\
\hline Current tax liability & $27.86 \%$ & $20.60 \%$ & $80.94 \%$ & $-39.26 \%$ \\
\hline Provisions & $-21.41 \%$ & $1.29 \%$ & $139.09 \%$ & $-2.55 \%$ \\
\hline Derivative financial liability & $245.95 \%$ & $65.10 \%$ & $-52.84 \%$ & $-85.28 \%$ \\
\hline Revenue received in advance & $-5.89 \%$ & $-7.62 \%$ & $14.93 \%$ & $-3.93 \%$ \\
\hline Non-currentliabilities & $-9.92 \%$ & $-2.89 \%$ & $0.40 \%$ & $5.70 \%$ \\
\hline $\mathrm{NC}$ borrowings & $-19.38 \%$ & $-1.55 \%$ & $-1.81 \%$ & $19.69 \%$ \\
\hline NC provisions & $-4.47 \%$ & $-4.26 \%$ & $-62.07 \%$ & $4.55 \%$ \\
\hline Derivative financial liability & $85.35 \%$ & $18.51 \%$ & $30.57 \%$ & $-30.82 \%$ \\
\hline Deferred tax liability & $20.97 \%$ & $-10.22 \%$ & $-36.01 \%$ & $20.14 \%$ \\
\hline Equity & $2.58 \%$ & $-5.50 \%$ & $-4.91 \%$ & $10.15 \%$ \\
\hline Contributed equity & $0.25 \%$ & $0.36 \%$ & $0.45 \%$ & $1.35 \%$ \\
\hline Reserves & $14.29 \%$ & $170.19 \%$ & $2.85 \%$ & $-28.60 \%$ \\
\hline
\end{tabular}

Table 2. Trend analysis of income statement.

\begin{tabular}{|c|c|c|c|c|}
\hline Telstra's income statement & 2010 vs. 2009 & 2011 vs. 2010 & 2012 vs. 2011 & 2013 vs. 2012 \\
\hline Sales revenue & $-2.20 \%$ & $1.13 \%$ & $1.10 \%$ & $1.22 \%$ \\
\hline Service revenue & $-23.53 \%$ & $102.88 \%$ & $-36.02 \%$ & $123.70 \%$ \\
\hline Labour & $-10.26 \%$ & $5.85 \%$ & $26.58 \%$ & $-3.30 \%$ \\
\hline Goods and services purchased & $0.88 \%$ & $15.35 \%$ & $-0.06 \%$ & $3.40 \%$ \\
\hline Other expense & $-2.07 \%$ & $-1.37 \%$ & $-18.31 \%$ & $0.85 \%$ \\
\hline EBIT & $-0.87 \%$ & $-12.44 \%$ & $2.28 \%$ & $9.77 \%$ \\
\hline Net finance expense & $7.00 \%$ & $17.86 \%$ & $-21.76 \%$ & $2.36 \%$ \\
\hline Net Profit before tax & $-2.12 \%$ & $-17.71 \%$ & $8.27 \%$ & $11.11 \%$ \\
\hline Income tax expense & $1.01 \%$ & $-18.21 \%$ & $15.53 \%$ & $7.09 \%$ \\
\hline Net profit & $-3.34 \%$ & $-17.51 \%$ & $5.35 \%$ & $12.88 \%$ \\
\hline
\end{tabular}




\section{Vertical Analysis}

In order to perform the vertical analysis, the total revenue of each year was chosen as a base to compare with other components in the same year. According to the table above, the total revenue was primarily contributed by the sales revenue. It indicated that total revenue mostly came from its operating activities. However, the proportion of sales revenue declined from 99.47 to 98.84 and it was because, since 2009, Telstra started to expand and diversify its business. In practice, this slight adjustment in operation provided company an opportunity to mitigate some business risks. In addition, the total operating expense of each year ranged from 0.575 to
0.591 compared to the revenue. It resulted from higher labour cost and higher cost of purchases. However, from 2009 to 2013, the total expense was considered as steady when there was not any significant change. When fluctuations of both revenue and expense were taken into consideration, earnings before interest and tax of each year in the last 5 years was seen not change much (from 0.2571 to 0.2460 of the total revenue). Moreover, the net financing cost was steady over the last 5 years. However, if the net financing cost was compared to the operating profit in the same year, there was a significant increase on financing cost in 2013. To sum up, the revenue-based profit almost kept consistent over 5 years and it reflected Telstra's good profitable ability.

Table 3. Common size analysis of income statement.

\begin{tabular}{|c|c|c|c|c|c|}
\hline Telstra's balance sheet & 2009 & 2010 & 2011 & 2012 & 2013 \\
\hline Sales revenue & 0.9947 & 0.9958 & 0.9917 & 0.9947 & 0.9884 \\
\hline Other revenue & 0.0053 & 0.0042 & 0.0083 & 0.0053 & 0.0116 \\
\hline Total revenue & 1.0000 & 1.0000 & 1.0000 & 1.0000 & 1.0000 \\
\hline Other income & 0.0042 & 0.0045 & - & - & - \\
\hline Total income & 1.0042 & 1.0045 & 1.0000 & 1.0000 & 1.0000 \\
\hline Labour & -0.1620 & -0.1488 & -0.1551 & -0.1948 & -0.1849 \\
\hline Other expense & -0.2048 & -0.2054 & -0.1995 & -0.1617 & -0.1600 \\
\hline Operating expenses & -0.5751 & -0.5692 & -0.5989 & -0.5987 & -0.5908 \\
\hline Share of net profit from jointly controlled and associated entities & 0.0001 & 0.0001 & 0.0000 & - & -0.0000 \\
\hline Depreciation \& amortisation & -0.1721 & -0.1744 & -0.1762 & -0.1730 & -0.1631 \\
\hline EBIT & 0.2571 & 0.2609 & 0.2249 & 0.2283 & 0.2460 \\
\hline Net finance expense & -0.0353 & -0.0386 & -0.0449 & -0.0348 & -0.0350 \\
\hline Income tax expense & -0.0620 & -0.0641 & -0.0517 & -0.0592 & -0.0622 \\
\hline Net profit & 0.1598 & 0.1581 & 0.1284 & 0.1343 & 0.1488 \\
\hline
\end{tabular}

\section{Ratio Analyses}

\subsection{Liquidity Ratios}

Liquidity ratios measure the firm's ability to satisfy its short-term obligations as they come due which is especially import ant to creditors, suppliers, management and others. The liquidity analysis includes number of critical following ratios.

The current ratio calculated by current assets/current liabilities is the best-known measures of liquidity, which measures short-term ability of an entity to pay its short-term bills and meet unexpected needs for cash. And the Quick ratio measures an entity's immediate short-term liquidity. As the Quick ratio excludes inventory and prepaid assets which are the least liquid current assets that is still an effective tool to measure the ability to meet short-term demands for cash, it equals to (cash + short-term investments + net receivable)/current liabilities.

According to the annual financial reports from 2009 to 2013, the Current ratio of Telstra was increasing steady expect a big jump at 1.05 in 2013. When we come back to the balance sheet, there was a large drop on borrowing which caused a reduction on total current liabilities and a rapid increase on the current ratio in 2013 .

Table 4. Liquidity ratio comparison in three companies from 2009 to 2013.

\begin{tabular}{|c|c|c|c|c|c|c|c|c|c|c|c|c|c|c|c|}
\hline & 2009 & & & 2010 & & & 2011 & & & 2012 & & & 2013 & & \\
\hline & $\mathbf{T}$ & $\mathbf{O}$ & $\mathbf{V}$ & $\mathbf{T}$ & $\mathbf{O}$ & $\mathbf{V}$ & $\mathbf{T}$ & $\mathbf{O}$ & $\mathrm{V}$ & $\mathbf{T}$ & $\mathbf{O}$ & $\mathrm{V}$ & $\mathbf{T}$ & $\mathbf{O}$ & $\mathrm{V}$ \\
\hline Current ratio & 0.80 & 0.74 & 0.47 & 0.83 & 0.75 & 0.50 & 0.87 & 0.77 & 0.63 & 0.93 & 1.05 & 0.83 & 1.05 & 0.83 & 0.75 \\
\hline Quick ratio & 0.77 & 0.71 & 0.45 & 0.79 & 0.70 & 0.48 & 0.84 & 0.73 & 0.61 & 0.91 & 1.01 & 0.81 & 0.99 & 0.79 & 0.73 \\
\hline
\end{tabular}

The table indicates the ratio was always kept under 1.00 before 2013 (table 1) which generally shows the company has negative working capital (equals current assets minus current liabilities) and probably faces a liquidity crisis. However, according to low inventory in the telecommunication industry, low current ratio of the company can be definitely accepted. It means that the majority of corporate assets focus on the None-Current assets like PPE and intangible. Although the Current ratio of Telstra was less than 1.00 but relatively higher when 
compared with Optus and Vodafone, it shows that Telstra has the advantage to pay its short-term bills in the telecommunication industry.

The quick and current ratios differ only in the assumed liquidity of the current assets that the projects will be used to pay off the current liabilities and the quick ratio describes a company's instant short-term liquidity. Due to the weak effects of inventory in this industry, the quick ratio gives the same result compared with the two others. In addition, with this ratio kept increasing from 2009 to 2013, the trend indicated that Telstra developed in the short-time liquidity management.

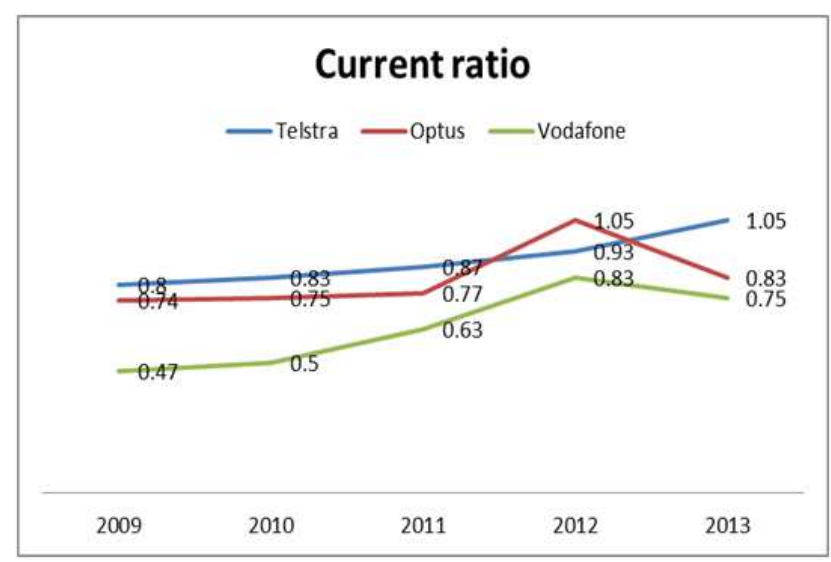

Figure 3. Trend comparison in current ratio from 2009 to 2013.

\subsection{Activity Ratios}

Receivable turnover measures the number of times on average receivables are collected during the period. It is measured by net credit sales/average net receivables. From the data in the table above, the receivable turnover of Telstra from 2009 to 2013 was relatively appropriate and steady from 7.92 to 7.54 . For the best illustration, the receivable turnover can be converted to the average days of collection which is the number of days it takes to for the company's customers to their bills. The average collection period of Telstra ranged with 46.11 to 48.41 days. It is a really good ratio compared to average collection period of Optus (nearly 50 days), but there exists a big gap from Vodafone (nearly 32 days).

In the analysis of accounts receivable in days, dialectical treating should be used. A collection period that is too high might mean that customers are too slow in paying their bills, which means too much capital is tied in assets, while a collection period that is too low might indicate that the firm's credit policy is too rigorous, which might be hampering sales. That means we should not focus on the Vodafone's efficiency of collection which is better than Telstra, but also consider whether the credit policy give customers much pressure. For Telstra, receivables turnover had decreased slightly about in the recent 5 years. Though it may be caused by a worse liquidity management, the receivables turnover of Telstra is still acceptable according to the situation of telecommunication industry.

Table 5. Activity ratio comparison in three companies from 2009 to 2013.

\begin{tabular}{|c|c|c|c|c|c|c|c|c|c|c|c|c|c|c|c|}
\hline & \multicolumn{3}{|l|}{2009} & \multicolumn{3}{|l|}{2010} & \multicolumn{2}{|l|}{2011} & \multicolumn{3}{|c|}{2012} & \multicolumn{3}{|c|}{2013} & \multirow[b]{2}{*}{ V } \\
\hline & $\mathbf{T}$ & $\mathbf{O}$ & V & $\mathbf{T}$ & $\mathbf{O}$ & V & $\mathbf{T}$ & $\mathbf{O}$ & V & $\mathbf{T}$ & $\mathbf{O}$ & V & $\mathbf{T}$ & $\mathbf{O}$ & \\
\hline $\begin{array}{l}\text { Accounts receivable } \\
\text { turnover ratio }\end{array}$ & 7.92 & 7.42 & 11.24 & 7.71 & 7.57 & 11.46 & 7.76 & 7.37 & 11.20 & 7.59 & 7.05 & 11.50 & 7.54 & 6.48 & 11.28 \\
\hline $\begin{array}{l}\text { Accounts receivable in } \\
\text { days }\end{array}$ & 46.11 & 49.22 & 32.48 & 47.35 & 48.23 & 31.84 & 47.05 & 49.51 & 32.59 & 48.07 & 51.79 & 31.73 & 48.41 & 56.34 & 32.36 \\
\hline
\end{tabular}

Table 6. Account payables turnover and account receivables turnover.

\begin{tabular}{|c|c|c|c|c|c|c|c|c|c|c|c|c|c|c|c|}
\hline & \multicolumn{3}{|l|}{2009} & \multicolumn{3}{|l|}{2010} & \multicolumn{3}{|l|}{2011} & \multicolumn{3}{|l|}{2012} & \multicolumn{3}{|l|}{2013} \\
\hline & $\mathbf{T}$ & $\mathbf{O}$ & $\mathbf{V}$ & $\mathbf{T}$ & $\mathbf{O}$ & $\mathbf{V}$ & $\mathbf{T}$ & $\mathbf{O}$ & $\mathbf{V}$ & $\mathbf{T}$ & $\mathbf{O}$ & $\mathbf{V}$ & $\mathbf{T}$ & $\mathbf{O}$ & $\mathbf{V}$ \\
\hline $\begin{array}{l}\text { Accounts payable } \\
\text { turnover }\end{array}$ & 7.04 & 7.98 & 8.44 & 6.49 & 7.35 & 9.19 & 6.83 & 8.22 & 8.02 & 5.62 & 8.73 & 7.02 & 5.06 & 8.15 & 6.88 \\
\hline $\begin{array}{l}\text { Accounts payable } \\
\text { turnover in days }\end{array}$ & 51.87 & 45.75 & 43.25 & 56.21 & 49.68 & 39.73 & 53.42 & 44.39 & 45.49 & 64.92 & 41.80 & 52.03 & 72.13 & 44.77 & 53.03 \\
\hline
\end{tabular}

Moreover, accounts payable turnover measures the numbers of times on average the bills are paid during the period. It is calculated by cost of sales/average inventory. For Telstra, accounts payable turnover kept decreasing for the 5 years from 7.04 to 5.06, which indicates that the company has improved the effectiveness of accounts payable management. (Table 3) As similar to receivable turnover, the inventory turnover also can be converted to the inventory hold period for better comparison. The average accounts payable days of Telstra was relatively higher (ranged from 51.87 to 72.13 days) compared to the turnovers of Optus (from 41.80 to 49.68 ) and
Vodafone (from 39.73 to 53.03).The high average accounts payable days provide Telstra sufficient money on hand compared with two others. And what should be pointed out is that not the higher average accounts payable days mean the better accounts payable management. Though a company with a long payable period may utilize accounts payable as a source of short term funding with relatively little cost, it can damage relationships with supplies and lead to more restrictive credit terms. According to the big scales of assets in Telstra, the high accounts payable days can be accepted by its customers and provide a source of working capital to the firm. 


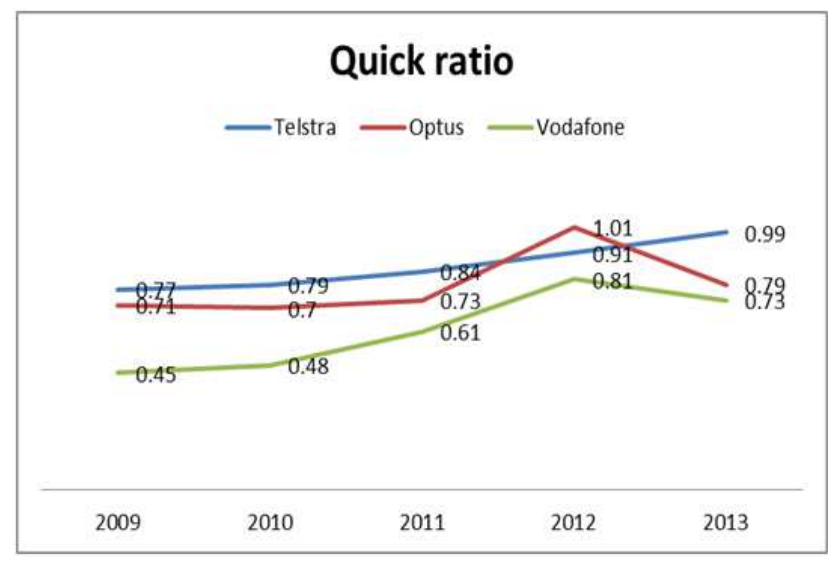

Figure 4. Trend comparison in quick ratio from 2009 to 2013.

\subsection{Profitability Ratio}

Profitability Ratios is a financial metric used to access a business's ability to generate earnings as compared to its expense and other relevant costs incurred during a specific period of time. Referring to the annual reports of Telstra, Optus and Vodafone from 2009 to 2013, the profitability ratios of these companies are presented in the above table.

\subsubsection{Net Profit Margin}

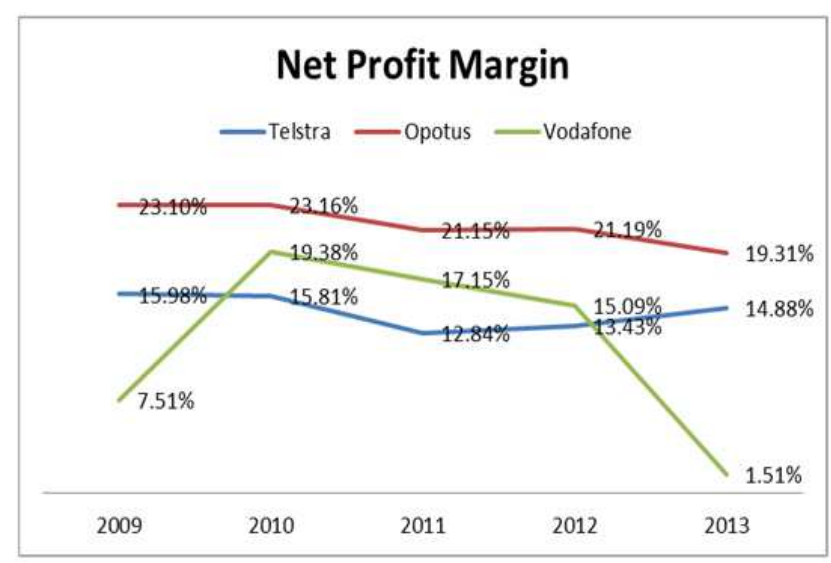

Figure 5. Trend comparison in net profit margin from 2009 to 2013.

Table 7. Net profit margin in three companies from 2009 to 2013.

\begin{tabular}{llllllllllllllll}
\hline & $\mathbf{2 0 0 9}$ & & \multicolumn{3}{c}{$\mathbf{2 0 1 0}$} & & & $\mathbf{2 0 1 1}$ & & $\mathbf{2 0 1 2}$ & & $\mathbf{2 0 1 3}$ & \\
\cline { 2 - 11 } & $\mathbf{T}$ & $\mathbf{O}$ & $\mathbf{V}$ & $\mathbf{T}$ & $\mathbf{O}$ & $\mathbf{V}$ & $\mathbf{T}$ & $\mathbf{O}$ & $\mathbf{V}$ & $\mathbf{T}$ & $\mathbf{O}$ & $\mathbf{V}$ & $\mathbf{T}$ & $\mathbf{O}$ & $\mathbf{V}$ \\
\hline $\begin{array}{l}\text { Net profit } \\
\text { margin }\end{array}$ & $15.98 \%$ & $23.10 \%$ & $7.51 \%$ & $15.81 \%$ & $23.16 \%$ & $19.38 \%$ & $12.84 \%$ & $21.15 \%$ & $17.15 \%$ & $13.43 \%$ & $21.19 \%$ & $15.09 \%$ & $14.88 \%$ & $19.31 \%$ & $1.51 \%$ \\
\hline
\end{tabular}

Net Profit Margin measures how much out of every dollar of sales a company actually keeps in earning. It shows efficiency of company is and its ability to control cost. The following figure shows the changes of the ratio of these companies over the last 5 years.

In generally, the net profit margin of Telstra was kept decreasing from $15.98 \%$ to $12.84 \%$ in 2009 to 2011 before they rose up back to $14.88 \%$ in the two following years. Although the Sales revenue did not have a significant change during 2009 to 2011, the Goods and Services purchased expense and the net finance expenses were both increased in these two years. Thus, it resulted in the decrease on the net profit margin. However, start from the Financial Year 2012, the net finance expense is dropped back a little bit because of newly borrowings, and this lead the net profit margin rose back to $14.88 \%$.

In comparison to Telstra, the net profit margin of Optus had a similar trend with Telstra. Both of them dropped from 2009 to 2011, the difference between the two companies is the net profit Margin of Optus was keep dropping in 2013 after the little raise back in 2012. Furthermore, Optus's net profit margin was higher than Optus over the last five years. For Vodafone, it has a completely different trend compare to Telstra, they had a magnificent increased in 2009 but there was a significant dropped afterward. The main reason is their sales revenue dropped a lot since most of their customers were transferred to Telstra.

In general, it is believed that Telstra successfully maintained its net profit margin in a stable trend over last the 5 years compared to other competitors and its profit margin was estimated to keep growing in future years.

\subsubsection{Return on Assets (ROA)}

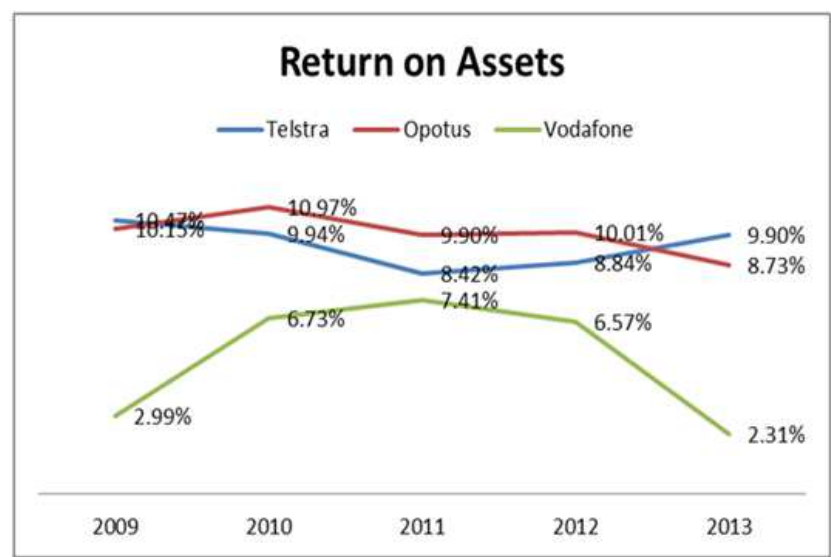

Figure 6. ROA of three companies from 2009 to 2013.

Return of Assets means how profitable a company is relative to its total assets. It also gives an idea as to efficiency of management in using its assets to generate earnings. According to the following figure, the ROA of Telstra had slightly changes over the past five financial years. From 2009 to 2011 , ROA of Telstra dropped from $10.47 \%$ to $8.42 \%$. But it rose up again from 2011 to $2013,8.42 \%$ back to $9.90 \%$. The decline of ROA from 2009 to 2011 was a result from a decline on the Net Profit Margin at that period. In analysis of the three companies, the ROAs of Telstra and Optus apparently 
overweighted that of Vodafone all the time. It was explained that Vodafone was a multinational company and it was more vulnerable to influence of financial crisis around the world in these years. In addition, overexpandedbranches made it get stuck in financial troubles.

Table 8. ROA in three companies from 2009 to 2013.

\begin{tabular}{|c|c|c|c|c|c|c|c|c|c|c|c|c|c|c|c|}
\hline & 2009 & & & 2010 & & & 2011 & & & 2012 & & & 2013 & & \\
\hline & $\mathbf{T}$ & $\mathbf{O}$ & $\mathbf{V}$ & $\mathbf{T}$ & $\mathbf{O}$ & $\mathbf{V}$ & $\mathbf{T}$ & $\mathbf{O}$ & $\mathbf{V}$ & $\mathbf{T}$ & $\mathbf{O}$ & $\mathbf{V}$ & $\mathbf{T}$ & $\mathbf{O}$ & $\mathbf{V}$ \\
\hline ROA & $10.47 \%$ & $10.15 \%$ & $2.99 \%$ & $9.94 \%$ & $10.97 \%$ & $6.73 \%$ & $8.42 \%$ & $9.90 \%$ & $7.41 \%$ & $8.84 \%$ & $10.01 \%$ & $6.57 \%$ & $9.90 \%$ & $8.73 \%$ & $2.31 \%$ \\
\hline
\end{tabular}

\subsubsection{Return on Equity (ROE)}

Return of Equity is the amount of net income returned as a percentage of shareholders equity. It measures a corporation's profitability by revealing profit a company generates with the money shareholders have invested. Referring to the figure,
ROE's of Telstra decrease from $32.70 \%$ to $25.69 \%$ during 2009 to 2011 and rose back to $31.47 \%$ in 2013 . In generally, the ROE of Telstra was the highest compared to Optus and Vodafone, and ROE of these 3 companies remain quite steady in the over last five years.

Table 9. ROE in three companies from 2009 to 2013.

\begin{tabular}{|c|c|c|c|c|c|c|c|c|c|c|c|c|c|c|c|}
\hline & 2009 & & & 2010 & & & 2011 & & & 2012 & & & 2013 & & \\
\hline & $\mathbf{T}$ & O & V & $\mathbf{T}$ & O & $\mathbf{V}$ & $\mathbf{T}$ & O & $\mathbf{V}$ & $\mathbf{T}$ & O & $\mathbf{V}$ & $\mathbf{T}$ & O & $\mathbf{V}$ \\
\hline ROE & $32.70 \%$ & $16.70 \%$ & $3.82 \%$ & $30.67 \%$ & $17.75 \%$ & $9.82 \%$ & $25.69 \%$ & $15.98 \%$ & $8.82 \%$ & $28.56 \%$ & $16.69 \%$ & $8.45 \%$ & $31.47 \%$ & $14.80 \%$ & $0.89 \%$ \\
\hline
\end{tabular}

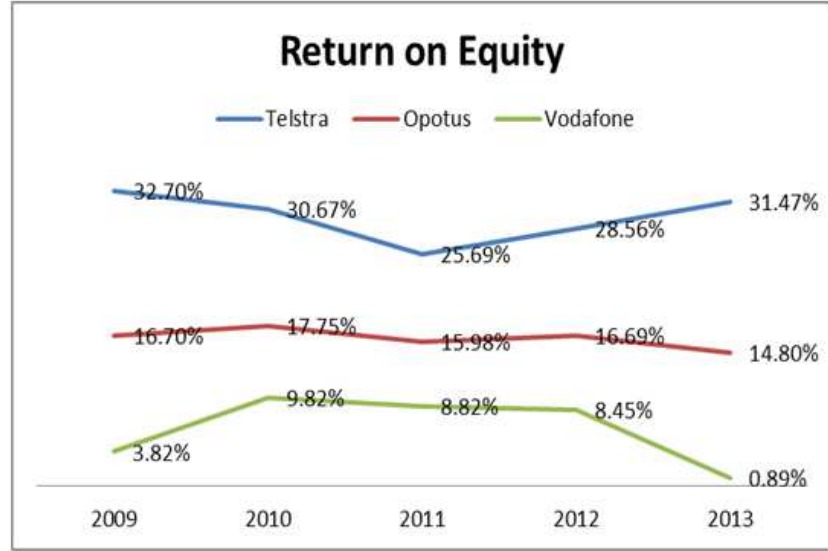

Figure 7. ROE of three companies from 2009 to 2013.

\subsection{Gearing Ratio}

\subsubsection{Debt to Total Assets Ratio}

Debt to Total Assets Ratio is an indicator of financial leverage. It tells the percentage of total assets that were financed by creditors, liabilities and debt. It has a slight change that Telstra's debt to total assets ratio decreased from 0.43 to 0.39 . As the debt of Telstra is keep decreasing but total assets didn't change much. This is the reason why the ratio dropped.

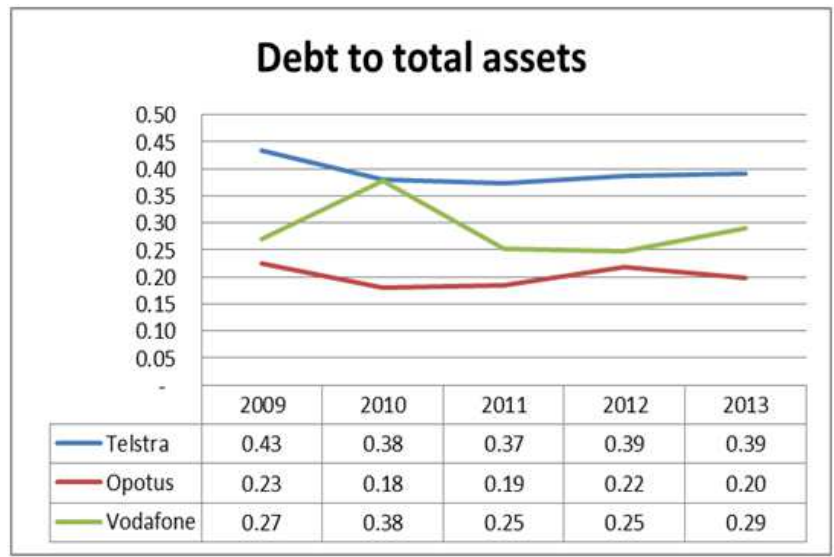

Figure 8. Debt to Total Assets Ratio.

Table 10. Debt to total assets in three companies from 2009 to 2013.

\begin{tabular}{|c|c|c|c|c|c|c|c|c|c|c|c|c|c|c|c|}
\hline & 2009 & & & 2010 & & & 2011 & & & 2012 & & & 2013 & & \\
\hline & $\mathbf{T}$ & $\mathbf{O}$ & $\mathbf{V}$ & $\mathbf{T}$ & $\mathbf{O}$ & $\mathbf{V}$ & $\mathbf{T}$ & $\mathbf{O}$ & $\mathbf{V}$ & $\mathbf{T}$ & $\mathbf{O}$ & $\mathbf{V}$ & $\mathbf{T}$ & $\mathbf{O}$ & $\mathbf{V}$ \\
\hline Debt to total assets & 0.43 & 0.23 & 0.27 & 0.38 & 0.18 & 0.38 & 0.37 & 0.19 & 0.25 & 0.39 & 0.22 & 0.25 & 0.39 & 0.20 & 0.29 \\
\hline
\end{tabular}

Compare to Telstra, Vodafone maintained the debt to total assets ratio to be stable during 2011 to 2013. However, there was a significant change during 2009 to 2011. It is more fluctuate than Telstra. For Optus, their debt to total assets ratio maintained a very stable level over the past 5 years.

\subsubsection{Interest Cover Ratio}

Interest Cover Ratio is a ratio used to determine how a company can pay interest on outstanding debt. In general, Telstra and Optus have a similar Interest Cover Interest. It proves that these two companies have an equivalent ability to meet interest payments to sustain debt. However the interest cover ratio of Optus is much higher than Telstra. Therefore Optus will act a better role in interest covered from overall trend. 
Table 11. Interest cover ratio in three companies from 2009 to 2013.

\begin{tabular}{|c|c|c|c|c|c|c|c|c|c|c|c|c|c|c|c|}
\hline & 2009 & & & 2010 & & & 2011 & & & 2012 & & & 2013 & & \\
\hline & $T$ & $\mathbf{O}$ & $\mathbf{V}$ & $\mathbf{T}$ & $\mathbf{O}$ & $\mathbf{V}$ & $T$ & $\mathbf{O}$ & $\mathbf{V}$ & $T$ & $\mathbf{O}$ & $\mathbf{V}$ & $T$ & $\mathbf{O}$ & $\mathbf{V}$ \\
\hline Interest cover ratio & 7.29 & 12.29 & 2.73 & 6.75 & 14.87 & 6.74 & 5.01 & 13.93 & 6.95 & 6.56 & 13.22 & 5.94 & 7.03 & 15.07 & 2.82 \\
\hline
\end{tabular}

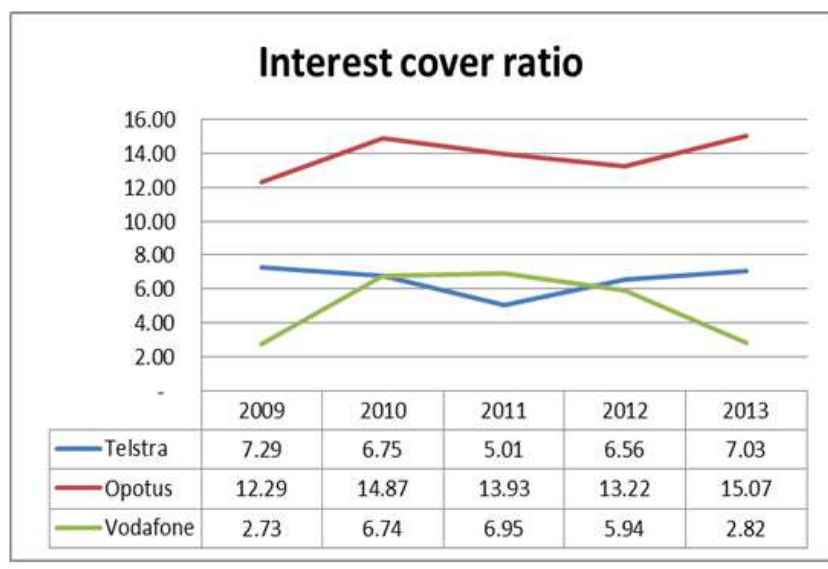

Figure 9. Interest cover ratio.

For the Vodafone, their Interest Cover Ratio fluctuates from 2.73 to 6.74 during 2009 to 2010 , and 6.74 to 2.82 during 2010 to 2013. Since Vodafone has a lower ratio, it means Vodafone is burdened more by debt expensive. They will have an easier chance to fall into bankruptcy as their ability to meet interest expenses is weaker than the other two companies.

\subsubsection{Long-Term Debt to Assets}

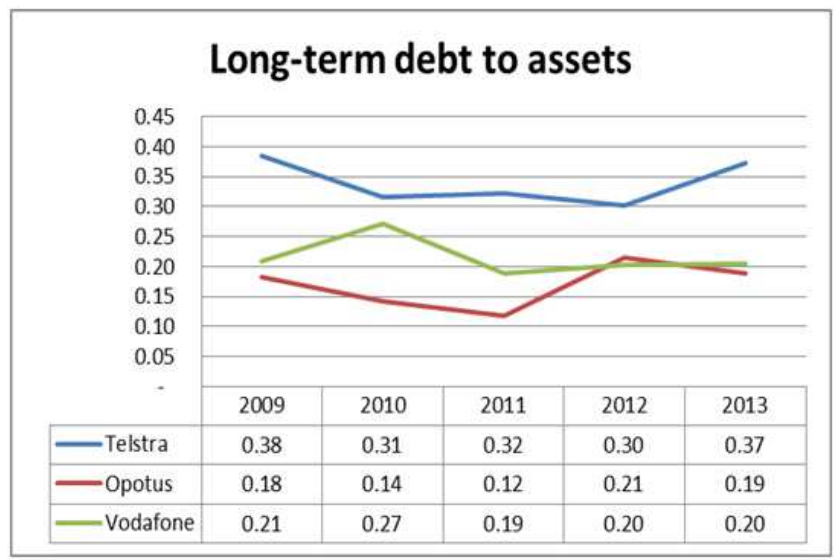

Figure 10. Long-term debt to assets.

Table 12. Long-term debt to assets in three companies from 2009 to 2013.

\begin{tabular}{|c|c|c|c|c|c|c|c|c|c|c|c|c|c|c|c|}
\hline & 2009 & & & 2010 & & & 2011 & & & 2012 & & & 2013 & & \\
\hline & $\mathbf{T}$ & O & $\mathbf{V}$ & $\mathbf{T}$ & O & $\mathbf{V}$ & $\mathbf{T}$ & O & $\mathbf{V}$ & $\mathbf{T}$ & O & $\mathbf{V}$ & $\mathbf{T}$ & O & $\mathbf{V}$ \\
\hline $\begin{array}{l}\text { Long-term debt to } \\
\text { assets }\end{array}$ & 0.38 & 0.18 & 0.21 & 0.31 & 0.14 & 0.27 & 0.32 & 0.12 & 0.19 & 0.30 & 0.21 & 0.20 & 0.37 & 0.19 & 0.20 \\
\hline
\end{tabular}

Long Term Debt to Assets Ratio is a measurement representing the percentage of a corporation's assets that are financed with loans and financial obligation that are more than one year. And the ratio will provides a general measure of the financial position of a company.

Comparing of these three companies, all of them have a steady long-term debt to assets ratio in the over past 5 years. The ratio did not fluctuate much. However, Telstra has a higher Long-term debt to assets ratio compare to the others two companies. It means Telstra is more dependent on debt to grow their business. Therefore, the management of Telstra should draw more attention to utilization of its asset to protect them from default risks.

\subsection{Earnings per Share (EPS)}

EPS is the simpler method to categorize outstanding shares, as it uses the number of shares currently available for trading; basically it means the profit on each ordinary share issued. According to the table 4, the EPS of Telstra took the first place by fluctuating from 26.1 to 32.9 during the 5 years. In addition, Telstra successfully maintained the EPS always above 25 cents for last 5 years. Moreover, EPS of Telstra was always 2 to 30 times higher than EPS of Vodafone. There, Telstra can maximized their profit by earning on each shares compared to their competitors. In comparison, it was believed that Telstra was absolutely potential in the future and it would maintain its market share in telecom industry.

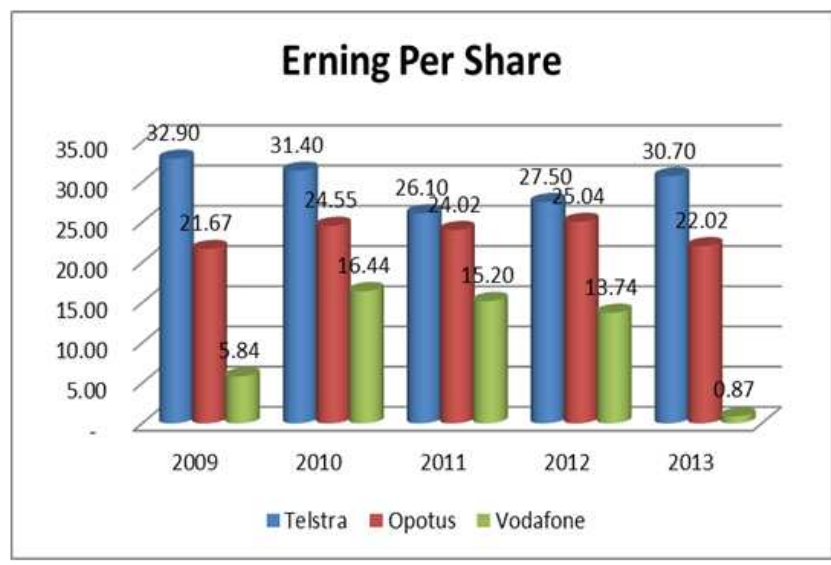

Figure 11. EPS of three companies from 2009 to 2013.

Table 13. EPS in three companies from 2009 to 2013.

\begin{tabular}{|c|c|c|c|c|c|c|c|c|c|c|c|c|c|c|c|}
\hline & 2009 & & & 2010 & & & 2011 & & & 2012 & & & 2013 & & \\
\hline & $\bar{T}$ & $\mathbf{O}$ & $\mathbf{V}$ & $\mathbf{T}$ & $\mathbf{O}$ & $\mathbf{V}$ & $\mathbf{T}$ & $\mathbf{O}$ & $\mathbf{V}$ & $\mathbf{T}$ & $\mathbf{O}$ & V & $\mathbf{T}$ & $\mathbf{O}$ & $\mathbf{V}$ \\
\hline Earnings per Share & 32.90 & 21.67 & 5.84 & 31.40 & 24.55 & 16.44 & 26.10 & 24.02 & 15.20 & 27.50 & 25.04 & 13.74 & 30.70 & 22.02 & 0.87 \\
\hline
\end{tabular}




\section{Conclusion}

Overall, the report has analysed the social, economic and industry background of Telstra which includes business model and media disclosure. Afterward, we make analysis about Telstra's financial performance and make a comparison between Telstra and its main competitors, Optus and Vodafone. According to horizontal, vertical and ratio analysis of the three companies, we find out that Optus's profitability and capital structure perform better.

Based on the external factors, business environment, the financial analysis and the estimated future share price, it is strongly recommended that Telstra is a good investing choice for investors and it will be seen beneficial in both short run and long run.

\section{References}

[1] Bloomberg, 2013. Telstra Corporation Limited.
[2] Bloomberg, 2013. TELSTRA CORPORATION LIMITED.

[3] LeMay, R., 2012. Warning: Telstra is killing off Australia's mobile competition.

[4] Optus, 2009-2013. Optus Annual Report 2009-2013.

[5] Telstra CorporationLimitedAnd Deloitte Digital, 2012. Taking Leadership in A Digital Economy.

[6] Telstra, 2009-2013. Telstra Annual Report 2009-2013.

[7] The Advocate, 2013. Telstra's deal.

[8] THE AUSTRALIAN, 2013. Telstra Seeking New Savings As It Expands 4G, Focus on Asia.

[9] THE AUSTRALIAN, 2013. Telstra Seeking New Savings As It Expands 4G, Focus on Asia.

[10] Vodafone, 2009-2013. Vodafone Annual Report 2009-2013

[11] Wilkins, G., 2013. Massive job cuts by Telstra. 